\title{
Compliance of the Goals of Modern Family Policy with the Development Processes of the Modern Family
}

\author{
Natalya Ignatyeva ${ }^{1},{ }^{*}$ Natalya Bukhalova ${ }^{1}$ \\ ${ }^{I}$ Nizhny Novgorod State Engineering and Economic University, Nizhny Novgorod, Russia \\ *Email: ngieikonkova@yandex.ru
}

\begin{abstract}
The article analyses the legislation of the Russian Federation and several developed countries in the field of marital and family relations, as well as the goals and directions of the development of the social institution of the family within the framework of strategies and concepts approved by the state. The article presents data and opinions of researchers on the current state and forms of family relations. Hypotheses about the crisis of traditional family relations, nuclearisation and atomisation of the family are considered. The authors conclude that the attempts made to correlate the goals of state demographic and economic policy with the achievement of social justice are not effective in the absence of a full-fledged and functioning set of mechanisms for supporting the family institution in legislative and executive practice, taking into account the trends existing in society to abandon the accepted understanding of the family.
\end{abstract}

Keywords: Atomisation, Marriage and family relations, Inclusivity, Nuclear family, Traditional family.

\section{INTRODUCTION}

To date, many sociologists, historians, and philosophers are concerned about aspects of the family's current position in society. In recent decades, rapid technological progress, economic growth, and the development of collective consciousness in the diversity of forms of family interaction have led to the need to reconsider the importance of marriage and family relations for building a stable social structure. The article examines the trends that could be traced in various states' legislation and social strategies related to the vectors of social development and considered national values and aspirations.

The analysis shows that, on the one hand, there are attempts to preserve traditional forms and values of family and marriage relations, such as reducing the number of divorces, supporting large families, raising children in the bosom of the family, inclusiveness of the family environment for socially unprotected members of society. On the other hand, the needs of society in the adoption of new forms of marriage and family relations at the legislative level and the creation of mechanisms to support them are apparent.
National strategies for the development of society are united by the desire to realise equality and social justice, which should contribute to the modernisation and even revolution of family law.

At the same time, within the framework of individual states, there are no transparent legal systems and mechanisms for fixing and analysing the dynamics of family change processes that would allow building clear conditions within which the family in its modern form could progressively develop. Modern researchers raise the question of the consistency and effectiveness of the measures taken by the authorities, their compliance with the trends of requests and aspirations of the society.

For a long time, family relations as a social construct were in a fairly stable position, being the basis of many social formats, starting with the primitive communal system. Various reasons determined the stability of the system: the need to preserve and raise offspring, the material dependence of some family members on others, the transfer of generational experience, customs and traditions of society, following religious precepts, etc. Today, there is a qualitative 
transformation of the institutions of family and marriage and the expansion of the range of their forms. Some researchers call the current state of family and marriage relations a crisis, as more and more people favour nontraditional families. Thus, K. Chang admits that in developed Eastern countries, the family is going through a phase of decline due to the individualisation of the community, linking this process with the dynamic restructuring of society [1]. Extensive research has been conducted within the framework of the "New Family Structure Study" in same-sex parental relationships and their role in stabilising the family phenomenon. Critics of this study also touch upon the aspect of instability of family and marriage relations [2].

A significant contribution to the theory of "family decline" was made by the sociologist K. Laplant who proclaimed the decline of the traditional family as a social tool intended to reproduce the population and the upbringing of future adults [3]. It should be noted that this hypothesis was previously expressed in relation to developed countries, such as the USA, Sweden, Switzerland, etc., in the works of D. Popenoe [4]. Within the framework of this hypothesis, we are talking about changing the essence of the concept of family, its definition, and distinctive central features. The article's authors have also previously expressed assumptions that qualitative changes in family and marriage relations are a global trend but look more pronounced in developed countries [5].

\section{METHODOLOGY}

The article examines and compares legislative acts regulating the diversity of family and marriage relations, discusses family development strategies and the expected results of support measures on the example of the EU, the USA, the Russian Federation, the UK and other countries. In this regard, a comparative analysis of policy concepts in family and marriage relations becomes relevant to identify the dependencies of the general attitudes of the development of the state and family policy. Researchers' conclusions on the transitional state of the family institution and views on family policy promoted by state institutions of various countries are presented.

The paper also presents an analysis of the research of domestic and foreign scientists in the field of sociology and philosophy of the family, research on the effectiveness of state family policy. The study results by sociologists, gerontologists, psychologists from Russia, the USA, the UK, and EU legislative acts regulating family relations and aimed at supporting the human family ecosystem were subjected to secondary analysis.

\section{STUDY RESULTS}

In connection with the transformation of the concept of the social phenomenon of family and marriage and the expansion of the range of their forms, there is also a need to create and introduce new types of support, resulting in a new legislative framework and social services. More and more attention to particular forms of family relations is required from the state. According to the data of the public European portal "COFACE" [6], the state and public organisations should support modern families in the following areas:

- social inclusion;

- poverty prevention;

- gender equality;

- financial inclusion;

- independence for people with disabilities;

- the rights of the child;

- inclusiveness of education;

- work-life balance.

It is assumed that the family receives appropriate support within the framework of such EU legislative acts as the Directive of the European Parliament and the Council on work-life balance for parents and Guardians of 2019 [7]; Gender Equality Strategy for 2020-2025 [8]; Strategy for the Protection of the Rights of Persons with Disabilities for 2021-2030 [9]; EU Strategy for the Rights of the Child [10]; European Pillar of Social Rights [11].

As for family legislation in general, there is no single system of mechanisms designed to regulate family relations in the Western legal tradition. For example, the EU family law affects only such cases as, for example:

- cross-border divorce;

- cross-border custody of children;

- cross-border succession in the event of the death of a spouse (relative).

Thus, there is no single European system of family legislation, which is explained by the existence of different forms of family relations at the level of each member state [12].

On the example of the United Kingdom and the United States, we see the same trends: no single set of laws would allow solving issues related to marriage, children, and kinship. So, in the UK, the "Family Law Act of 1996" partially operates, but many of its articles have undergone significant changes or have been shortened and transferred to the "Children and Families Act of 2014", that is, two basic parallel laws are in force 
simultaneously, complementing each other. It should be noted that in the law of 2014, only the second section, "Family justice", is devoted to family relations proper [13]. Great attention is paid in the British family policy to the issues of child poverty, children's rights in general. Thus, recent studies show that the atomisation of society, the gender revolution in the labour market leaves children as a social category extremely unprotected [14].

The US legislative system also does not assume a single set of laws concerning the family. Thus, V. Hamilton notes that certain acts regulate specific areas of family life, such as adoption, marriage, maternity leave, and child protection. But all of them belong to different sets of legal documents (strategies, amendments, acts) with unequal force [15]. This vector of development, in our opinion, is caused by the lobbying of various trends within the framework of case law, but in this way, it encourages the building of the potential to influence the institution of the family of those controlling bodies and mechanisms that previously had no direct relation to it [16].

Marital relations are the most controversial concept in Russian and Western social practices. Thus, the recognition of same-sex relationships has led Western countries to the need to legislate new forms of family relations, such as partnership or cohabitation [17].

There is a set of laws covering many aspects of family relations in the Russian Federation. The Family Code contains 8 main sections concerning the basics of family law, marriages and divorces, the rights and obligations of spouses, children and parents, alimony obligations of family members, forms of child-rearing, etc. [18].

Many authors note that state family support measures are influenced mainly by the definition of family and marriage relations, adopted as a basis in the documents regulating them.

A look at the essence and significance of the family in the context of society also determines the vector of its development, the diversity of its forms, the understanding of the "ideal family". For example, the above-mentioned "Family Law Act 1996" of the United Kingdom specifies the following fundamental principles: the institution of marriage should be supported; parties to a marriage that may have broken up should be encouraged to take all practicable measures, whether through marriage counselling or otherwise, to preserve the marriage. According to part "g" of Article 72 of the Constitution of the Russian Federation: "The joint jurisdiction of the Russian Federation and the subjects of the Russian Federation is the protection of the family, motherhood, fatherhood and childhood; the protection of the institution of marriage as a union of men and women; the creation of conditions for decent upbringing of children in the family, as well as for adult children to take care of their parents" [19].

According to the Concept of state family Policy in the Russian Federation for the period up to 2025, the priorities of state family policy at the present stage are the establishment of traditional family values and family lifestyle, the revival and preservation of spiritual and moral traditions in family relations and family education, the creation of conditions for ensuring family well-being, responsible parenthood, increasing the authority of parents in the family and society and maintaining the social stability of each family [20]. Thus, state support measures aim to overcome the crisis state of the institution of the family as a building material of society as a whole. Nevertheless, Russian society tends to liberalise the gender roles of spouses [21], and the level of educational and financial responsibility of parents is also decreasing. Thus, "over the past three years, the number of cases on the recovery of child support has been increasing," which directly indicates the refusal of responsible persons to follow the laws on the fulfilment of financial obligations [22]. In addition, cases of complaints, primarily by single mothers, about the inefficient work of social services (non-payment of benefits, inaction of law enforcement agencies, improper maintenance of orphans) are becoming more frequent. I.e. despite the existence of laws and procedures for assisting families in difficult situations, not all steps to overcome the crisis are being implemented, primarily for disadvantaged families [23].

Despite all the variety of forms of family support as the basis of society, statistics speak about the crisis of traditional family and marriage relations. A decrease in the number of people getting married (Fig. 1) can also be traced in developed and developing countries.

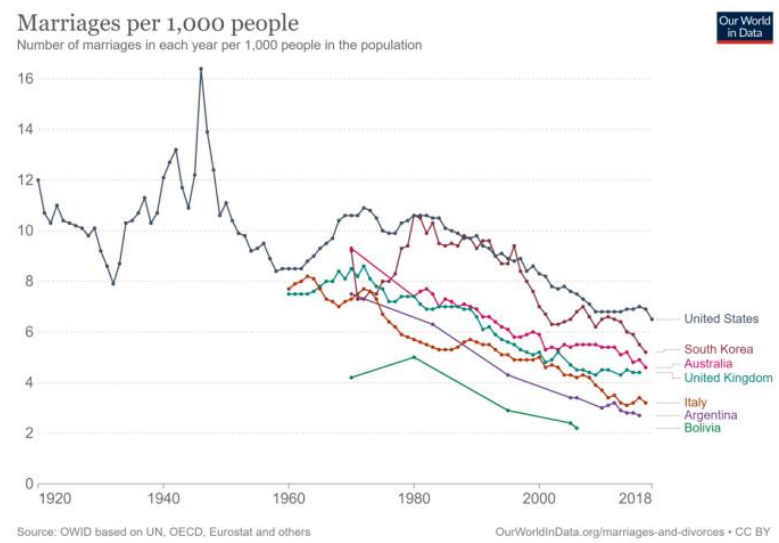

Figure 1 Number of marriages in each year per 1,000 people in the population (period from 1920 till 2018) [24].

Other forms of social partnership are becoming more preferable, providing, for example, regulation of only financial obligations or inheritance rights and having 
little in common with traditional family forms. The number of divorces also affects the number of remarriages. In the USA, for example, such a form of relations as "mixed families" is developing, where children and other relatives from previous marriages of spouses lead a life together. In many countries, such a type of family as a single parent and children has developed. According to N.Yu. Egorova, the change in the family structure is accompanied by such trends as a decrease in the birth rate, a decrease in the average size of the family, a change in the structure of parenthood, tolerance for divorce, a shift in the value priorities of members of society [25]. The discrepancy between the vectors of family development desired and advertised by state strategies and the processes observed by researchers in real life can be called a dichotomy. The "strategic" family and the real family are opposites. Attempts to return to traditional forms of nepotism through non-systemic measures to stimulate fertility, increase financial stability and increase the degree of responsibility of its members are considered by some researchers as a violation of natural processes in society for the sake of demographic or economic policy [26].

\section{CONCLUSION}

The analysis of the existing strategies for developing the family institution shows the public authorities' desire to create effective management models of marriage and family relations, considering the diversity of their forms. Attempts are being made to correlate the goals of the state demographic and economic policy with the achievement of social justice. Nevertheless, there is no full-fledged and effectively functioning set of mechanisms to support the family institution, taking into account the social trends to move away from the traditional understanding of the family. In reality, there is a qualitative transformation according to the "clan family - nuclear family - atomic family" model. The current state of family policy and law is a set of separate actions and services designed to regulate emerging hotbeds of crisis locally.

\section{REFERENCES}

[1] K. Chang, Individualisation without Individualism: Compressed Modernity and Obfuscated Family Crisis in East Asia, Transformation of the Intimate and the Public in Asian Modernity 5 (2014) 37-62. DOI: https://doi.org/10.1163/9789004264359 003

[2] M.J. Rosenfeld, Revisiting the Data from the New Family Structure Study: Taking Family Instability into Account, Sociological Science 2 (2015) 478501. DOI: https://doi.org/10.15195/v2.a23

[3] K. Laplant, Family Decline Theory, The Wiley Blackwell Encyclopedia of Family Studies, John
Wiley \& Sons, Inc., 2016, pp. 78-93. DOI: https://doi.org/10.1002/9781119085621.wbefs248

[4] D. Popenoe, Disturbing the nest: family change and decline in modern societies, New York: A. de Gruyter, 1988, 416 p.

[5] N.A. Bukhalova, N.N. Ignatieva, Modern family: crisis or transformation? [Sovremennaya sem'ya: krizis ili transformaciya?] // Humanitarian Scientific Bulletin [Gumanitarnyj nauchnyj vestnik], Smolensk Sociological Centre LLC 5 (2020) 278-284.

[6] COFACE Families Europe. Retrieved from: https://coface-eu.org/about-us/

[7] Directive (EU) 2019/1158 of the European Parliament and of the Council of 20 June 2019 on work-life balance for parents and carers and repealing Council Directive 2010/18/EU. Retrieved from: https://eur-lex.europa.eu/legalcontent/EN/TXT/?uri=celex\%3A32019L1158

[8] Communication from the Commission to the European Parliament, the Council, the European Economic and Social Committee and the Committee of the Regions a Union of Equality: Gender Equality Strategy 2020-2025 COM/2020/152 final. Retrieved from: https://eurlex.europa.eu/legalcontent/EN/TXT/?uri=CELEX\%3A52020DC0152

[9] Union of Equality: Strategy for the Rights of Persons with Disabilities 2021-2030. Retrieved from:

https://ec.europa.eu/social/main.jsp?catId=738\&lan $\mathrm{gId}=$ en \&pubId=8376\&furtherPubs=yes

[10] Communication from the Commission to the European Parliament, the Council, the European Economic and Social Committee and the Committee of the Regions EU strategy on the rights of the child COM/2021/142 final. Retrieved from: $\quad$ https://eur-lex.europa.eu/legalcontent/en/TXT/?uri=CELEX\%3A52021DC0142

[11] European Pillar of Social Rights. Retrieved from: https://ec.europa.eu/info/strategy/priorities-20192024/economy-works-people/jobs-growth-andinvestment/european-pillar-social-rights_en

[12] Overview of family matters. Retrieved from: https://ec.europa.eu/info/policies/justice-andfundamental-rights/civil-justice/familylaw/overview-family-matters_en

[13] Children and Families Act 2014. Retrieved from: https://www.legislation.gov.uk/ukpga/2014/6/conte nts 
[14] N. Finch, Family Policies in the UK, Family Policies in the Context of Family Change, 2008, pp. 129-154. DOI: https://doi.org/10.1007/978-3531-90895-3 7

[15] V. Hamilton, Principles of U.S. Family Law, Faculty Publications 184 (2006) 31-73, Retrieved from: https://scholarship.law.wm.edu/facpubs/184

[16] O.G. Isupova, Demographic and family policy in different countries: Conceptual approaches and practices [Demograficheskaya i semejnaya politika $\mathrm{v}$ raznyh stranah: konceptual'nye podhody i praktiki] // Demographic Review [Demograficheskoe obozrenie], 2020, pp. 51-83.

[17] E.A. Isaeva, A.V. Sokolov, The legalisation of same-sex marriage: the implementation of the equality policy or the destruction of the institution of the family? [Legalizaciya odnopolyh brakov: realizaciya politiki ravenstva ili razrushenie instituta sem'i?] // Yaroslavl Pedagogical Bulletin [Yaroslavskij pedagogicheskij vestnik] 3 (2013) 109-112.

[18] The Family Code of the Russian Federation of 29.12.1995 N 223-FZ (as amended on 02.07.2021), [Semejnyj kodeks Rossijskoj Federacii ot 29.12.1995 N 223-FZ (red. ot 02.07.2021)]. Retrieved from: http://www.consultant.ru/document/cons_doc_LA W $8982 /$

[19] The Constitution of the Russian Federation (adopted by popular vote on 12.12.1993 with amendments approved during the all-Russian vote on 01.07.2020), Article 72 [Konstituciya Rossijskoj Federacii (prinyata vsenarodnym golosovaniem 12.12.1993 s izmeneniyami, odobrennymi $\mathrm{v}$ hode obshcherossijskogo golosovaniya 01.07.2020), Stat'ya 72]. Retrieved from:

http://www.consultant.ru/document/cons_doc_LA W 28399/c6e42f15d1b028b04b556f3f9ca32433ae $\underline{2 c c 969 /}$

[20] Order No. 1618-r of August 25, 2014, The Concept of State Family Policy in the Russian Federation for the period up to 2025 [Rasporyazhenie of 25 avgusta 2014 g. № 1618-r, Koncepciya gosudarstvennoj semejnoj politiki v Rossijskoj Federacii na period do 2025 goda]. Retrieved from: http://static.government.ru/media/files/MyVeIiu5N u8.pdf

[21] Y.S. Zadvornova, Trends in the transformation of gender roles in the modern Russian family [Tendencii transformacii gendernyh rolej $\mathrm{v}$ sovremennoj rossijskoj sem'e] // Woman in
Russian society [Zhenshchina v rossijskom obshchestve] 2(67) (2013) 32-40.

[22] Review of judicial practice in cases related to the recovery of alimony for minor children and disabled adult children (approved By the Presidium of the Supreme Court of the Russian Federation on 13.05.2015) [Obzor sudebnoj praktiki po delam, svyazannym so vzyskaniem alimentov na nesovershennoletnih detej, a takzhe na netrudosposobnyh sovershennoletnih detej (utv. Prezidiumom Verhovnogo Suda RF 13.05.2015)]. Retrieved from: http://www.consultant.ru/document/cons doc LA W 179609/7b51a95e19c01d45251fe05300ac2e6c0 84aa3d3/

[23] N.T. Otdelkina, T.N. Zakharkina, Legal issues of the family ecosystem, The human Family Ecosystem, NISOC [Pravovye voprosy semejnoj ekosistemy, Semejnaya ekosistema cheloveka, NISOC], 2018, pp. 67-78.

[24] M. Roser, E. Ortiz-Ospina, Marriages and Divorces. Retrieved from: https://ourworldindata.org/marriages-and-divorces

[25] N.Yu. Egorova, The modern family in the system of matrimony-parenthood-kinship, The human Family Ecosystem, NISOC [Pravovye voprosy semejnoj ekosistemy, Semejnaya ekosistema cheloveka, NISOC], 2018, pp. 34-53.

[26] M. Muravyeva, Traditional values and modern families: legal understanding of tradition and Modernity in contemporary Russia, Journal of Social Policy Research 12 (2014) 625-638. 